\title{
A EDUCAÇÃO HEBRAICA SEGUNDO THEOBALDO MIRANDA SANTOS
}

\author{
Rodrigo Augusto de Souza \\ UFPR \\ rodrigoaugustobr@yahoo.com.br
}

\begin{abstract}
RESUMO
Este trabalho tem por objetivo apresentar a educação hebraica segundo o pensamento de Theobaldo Miranda Santos (1904-1971). Para tanto, investigaremos o capítulo do manual didático "Noções de História da Educação" que tratou exclusivamente deste tema. Buscamos problematizar o tratamento oferecido pelo intelectual ao tema da educação hebraica. Considerando que Theobaldo publicou seu manual didático pela primeira vez em 1945, no período de hegemonia de ideologias como o fascismo e o nazismo, procuramos compreender as nuances da educação hebraica de acordo com seu pensamento. $\mathrm{O}$ surgimento do antissemitismo no plano político foi uma característica desse período histórico. O tratamento oferecido por Theobaldo Miranda Santos ao tema da educação hebraica consiste no objeto dessa investigação.

Palavras-chave: Educação Hebraica. Judaísmo. Intelectuais. Theobaldo Miranda Santos.

\section{THE HEBREW EDUCATION OF ACCORDING WITH THEOBALDO MIRANDA SANTOS}

\begin{abstract}
This paper aims to present Hebrew education of according with of thought Theobaldo Miranda Santos (1904-1971). To do so, we will investigate the chapter of the manual "Noções de História da Educação" which dealt exclusively with this issue. We seek to problematize the treatment offered by the intellectual to theme of Hebrew education. Whereas that Theobaldo published your teaching manual in 1945, the period of hegemony of ideologies such as fascism and Nazism, trying to understand the nuances of Hebrew education in accordance with your thinking. The treatment offered by Theobaldo Miranda Santos to the subject of Hebrew education is the subject of this investigation.
\end{abstract}

Keywords: Education Hebrew. Judaism. Intellectuals. Theobaldo Miranda Santos.

\section{Introdução}

Na classificação dos períodos relacionados com a história da educação, Theobaldo Miranda Santos (1904-1971), compreendeu a educação hebraica vinculada com o "tradicionalismo pedagógico" e, desse modo, pertencente às épocas da "pré-história e antiguidade oriental". O intento desse estudo é investigar a compreensão que o intelectual tinha da educação hebraica, segundo o seu manual didático "Noções de História da Educação". Os vínculos de Theobaldo com a Ação Católica e o Integralismo nos levam a investigar essa questão. Considerando que o Integralismo foi a face brasileira do fascismo durante a década de 1930 (BERTONHA 2004), buscamos entender se havia no 
pensamento de Theobaldo uma preocupação com a chamada "questão judaica". Esse era um tema recorrente nesse período histórico, sobretudo entre os intelectuais ligados ao nazifascismo. Alguns intelectuais integralistas, como Gustavo Barroso, por exemplo, demonstravam abertamente o seu antissemitismo. De acordo com Cancelli (1994, p.125), a polícia do Estado Novo, nos tempos de Getúlio Vargas, perseguia os judeus e alguns de seus importantes agentes tinham recebido treinamento na Gestapo, a famosa polícia da Alemanha nazista. Segundo a autora, havia até mesmo um acordo entre a polícia de Vargas e a Gestapo. Isso talvez explique a entrada tardia do Brasil na Segunda Guerra Mundial contra o nazi-fascismo.

A “questão judaica” já tinha sido apontada por Marx (2010), durante o século XIX, na Alemanha. $\mathrm{O}$ antissemitismo se disseminava entre alguns estados europeus, tais como a França e a Alemanha. A perseguição aos intelectuais judeus também era recorrente. Muitos deles buscaram o exílio e encontraram o refúgio em cidades cosmopolitas como Paris e Londres. Na Europa, o crescente antissemitismo levou ao aparecimento da conhecida "solução final", tal como foi definida por Hannah Arendt (2011, p. 98). Uma ideologia perversa como o nazismo buscou resolver a "questão judaica" com a "solução final", ou seja, os campos de extermínio dos judeus e demais "inimigos" da "revolução nacionalsocialista" na Alemanha.

Mesmo que Theobaldo Miranda Santos tenha escrito seu manual didático já próximo do final da grande guerra, vamos nos deter na análise desse tema, no mínimo considerado delicado para o período, principalmente entre os intelectuais que tiveram proximidade com o Integralismo. Havia indícios da "questão judaica" no pensamento do intelectual? Qual foi a abordagem que ele ofereceu a esse tema? Sobre essas questões o presente trabalho pretende se debruçar e apresentar algumas reflexões ao leitor.

\section{A Questão Judaica}

Buscamos explicar o que seria a "questão judaica" com base no pensamento de Karl Marx, especialmente por meio da sua obra "Sobre a questão judaica", publicada pela primeira vez em 1843. Essa explicação procura demonstrar no que consistia a "questão judaica". Para Marx (2010, p.33), essa temática estava relacionada com a busca da emancipação dos judeus alemães. Há a problemática dos judeus frente ao Estado cristão. Afirmou: "O Estado cristão só conhece privilégios. O judeu possui dentro dele o privilégio de ser judeu". A situação dos judeus na Alemanha do século XIX era bastante crítica, eles buscavam a emancipação e direitos. Marx ainda sinalizou para o preconceito religioso sofrido pelos judeus no Estado "cristão" alemão e também em outras partes do mundo.

Esse Estado fomentaria o preconceito com os judeus e não poderia de modo nenhum atender suas reivindicações. Foi categórico ao afirmar que "o Estado cristão não pode emancipar o judeu". Mais adiante, Marx (2010) enfatizou: "Judeus, [...] a vossa religião é a inimiga mortal do Estado" (p.34). Esse tema estava voltado para a emancipação política do judeu dentro do Estado dito cristão. Marx analisou também as realidades da França e da América do Norte (p.37-38). Nesse sentido, se trata de um conflito "que emerge entre o homem que professa uma religião particular e sua cidadania" $\mathrm{e}$ compreendeu que o assunto trataria da "divisão secular entre o Estado político e a sociedade burguesa". De acordo com seu pensamento haveria uma contradição que se 
interpõe no homem como judeu e cidadão (p.41). O Estado cristão seria permeado pela teologia, que "professa a confissão de fé do cristianismo". Por outras palavras, é o Estado que "ainda não ousa se proclamar como Estado, de forma secular, humana". Esse aparato estatal, imerso na teologia e na confissão da fé cristã, ainda não se secularizou, por isso ele é o "não Estado". Para Marx, "o assim chamado Estado cristão constitui, na verdade, a negação cristã do Estado, mas jamais a realização estatal do cristianismo" (p.43). Assim sendo, no "Estado germânico-cristão, a religião é uma 'questão econômica', assim como a 'questão econômica' é religião" (p.44).

Para Marx (2010, p.45), o Estado deveria emancipar-se do seu domínio religioso. "Esse Estado só consegue se libertar de seu tormento interior, tornando-se o carrasco da Igreja Católica". Foi incisivo ao entender que: "No assim chamado Estado cristão, o que tem validade é a alienação, e não o homem. O único homem que tem valor, o rei, é um ente diferenciado dos demais homens [...]. Nesse caso, portanto, o espírito religioso ainda não foi realmente secularizado". A questão do Estado cristão no pensamento de Marx apresenta uma complexidade que ultrapassa as possibilidades desse estudo, cabe-nos compreender a condição do judeu dentro dessa estrutura estatal.

Procuremos, antes, o mistério da religião no judeu real. Qual é o fundamento secular do judaísmo? A necessidade prática, o interesse próprio. Qual o culto secular do judeu? O negócio. Qual é o seu deus secular? O dinheiro. Agora sim! A emancipação em relação ao negócio e ao dinheiro, portanto, em relação ao judaísmo prático, real, seria a autoemancipação da nossa época (MARX, 2010, p.56).

Marx entendeu que o capitalismo se escondia por trás da chamada "questão judaica". Assim, conseguimos compreender sua afirmação: "O dinheiro é o deus zeloso de Israel, diante do qual não pode subsistir nenhum outro. O dinheiro humilha todos os deuses do homem - os transforma em mercadoria. O dinheiro é o valor universal de todas as coisas, constituído em função de si mesmo" (2010, p.58). Ora, sabemos que o pensador encontrou uma confusão entre a religião e a economia, e vice-versa. É importante distinguir que Marx não está tratando daquilo que chamou de judeu "sabático", isto é, praticante da religião, mas do judeu cotidiano, secular e real. Trata-se do indivíduo que se sente judeu mesmo sem ter uma prática religiosa ordinária.

Heinrich Heine também percebeu a forte presença do antissemitismo na Alemanha do século XIX. Referiu-se, sobretudo, ao crescente ódio aos judeus na região de Colônia. "Os obscurantistas de Colônia pensavam que a salvação do mundo estava ameaçada e, portanto, todos os meios, tanto mentiras como assassinatos, lhes pareciam permissíveis, sobretudo contra os judeus". Notou que essa crença contra os hebreus estava se popularizando. "As pobres classes inferiores, as crianças da miséria hereditária, já odiavam os judeus por seu tesouro acumulado, e aquilo que hoje se chama de ódio do proletariado contra os ricos na época se chamava de ódio aos judeus" (HEINE, 2010, p. 280).

Talvez podemos entender aquilo que Slavoj Zizek (2011a) sustentou ao defender que Deus é um fetiche para o judeu secular. Como compreender que pensadores judeus foram ateus, como Marx e Freud, por exemplo? Sentiam-se judeus (um conceito religioso), mas entendiam a religião como alienação e neurose, respectivamente. Lembrava Freud: "Não está nos planos tomar posição quanto ao valor de verdade das doutrinas religiosas. Basta que as tenhamos reconhecido em sua natureza psicológica como ilusão" (FREUD, 
2012, p. 89). Deus, para o judeu secular, é um fetiche que o ajuda a entender sua condição na sociedade. Antes de ser cidadão, ele é judeu, mesmo que não creia em Deus, que considere a fé religiosa um mecanismo neurótico e alienante. Deus, segundo Zizek, é o fetiche do judeu secular. Esse foi o judeu que interessou Marx.

Ainda quanto à crítica da religião elaborada por Freud, encontramos a crença em Deus como projeção e busca da figura paterna. Tal elaboração fica bastante compreensível na afirmação a seguir:

Mas o desamparo dos homens permanece, e, com ele, os deuses e o anseio pelo pai. Os deuses conservam sua tripla tarefa: afastar os pavores da natureza, reconciliar os homens com a crueldade do destino, em especial com a morte, e recompensá-los pelos sofrimentos e provações de que a convivência na cultura lhes impõe (FREUD, 2012, p. 59).

Em Moisés e o Monoteísmo, Freud (1975) sustentou que as condições políticas dos judeus, desde os tempos do antigo Israel, sempre foram desfavoráveis "ao desenvolvimento da ideia de um deus nacional exclusivo" e da mesma forma, na busca de declará-lo como "soberano universal do mundo" (p.82). Perguntava-se: "E onde foi que essa minúscula e onipotente nação achou a arrogância de declarar-se a si própria filha favorita do grande Senhor?” (p.83). Freud queria buscar as origens do monoteísmo judaico. Mas também investigou as origens do antissemitismo: "Um fenômeno de tal intensidade e permanência como o ódio do povo pelos judeus, deve, naturalmente, possuir um fundamento" (p.110). Entendeu que "os motivos mais profundos do ódio pelos judeus estão enraizados nas mais remotas eras passadas; operam desde o inconsciente dos povos, e acho-me preparado para descobrir que, a princípio não parecerão críveis" (p.111). Assim, fica claro que, na visão freudiana, o antissemitismo tem suas origens no inconsciente dos povos e, portanto, na irracionalidade. Da mesma forma, ele pode ser identificado em diferentes períodos da história humana.

Adorno e Horkheimer (2006) apontaram para a "questão judaica", tal como ela culminou na Alemanha e na Europa do início do século XX, como os "limites do esclarecimento" (p.139). A força das ideias iluministas de emancipação chegou a um antissemitismo vulgar, sobretudo na Alemanha e na França, nações de tradição iluminista. Pensando nos termos de uma dialética do esclarecimento, como os dois filósofos propõem, o antissemitismo seria o momento da negação da "aufklärung" (esclarecimento/iluminismo). Os filósofos sustentaram: "O patológico no antissemitismo não é o comportamento projetivo enquanto tal, mas a ausência de reflexão que o caracteriza" (p.156). Os judeus ocupavam a posição econômica de "enganados" e "seduzidos" pela ideologia liberal. O antissemitismo não pode ser desvencilhado da "ideologia da raça" (p.171). A respeito da relação entre cristianismo e judaísmo, argumentaram: "Os adeptos da religião do Pai são odiados pelos adeptos da religião do Filho porque acham que sabem tudo" (p. 148). Do ponto de vista do pensamento dialético, a negação do esclarecimento pela ideologia antissemita seria um elemento vital, tal como Hegel (2008) já havia sugerido. A negação da ideia é tão importante quanto a sua afirmação, pois permite o progresso do conhecimento. Para Zygmunt Bauman, o Holocausto teria demonstrado avesso da sociedade moderna.

O indizível horror que permeia nossa memória coletiva do Holocausto (ligado de maneira fortuita ao premente desejo de não encarar essa memória de frente) é a corrosiva suspeita de que o Holocausto possa ter 
sido mais do que uma aberração, mais do que um desvio no caminho de outra forma reto do progresso, mais do que um tumor canceroso no corpo de outra forma sadio da sociedade civilizada; a suspeita, em suma, de que o Holocausto não foi uma antítese da civilização moderna e de tudo que ela representa (ou pensamos que representa). Suspeitamos (ainda que nos recusemos a admiti-lo) que o Holocausto pode ter meramente revelado um reverso da mesma sociedade moderna cujo verso, mais familiar, tanto admiramos. E que as duas fases estão presas confortavelmente e de forma perfeita ao mesmo corpo (BAUMAN, 2013, p. 26).

Freud (2008) tratou da questão do antissemitismo nesses termos: "O Diabo seria a melhor desculpa para Deus, assumiria ele a função de descarga econômica que também recaiu sobre os judeus no mundo do ideal ariano" (p.77). A "questão judaica" tinha transformado a religião em assunto de Estado. Já o "sonho de um domínio germânico universal" apelou para "o antissemitismo" (p.69). O judeu, mesmo tendo prestado relevantes serviços na cultura ocidental, nas artes e nas ciências, era um "obstáculo" para as grandes "potências caucasianas" (p.114). Podemos sustentar que os grandes conflitos bélicos do século XX foram guerras entre "raças" tidas como superiores e inferiores. O adversário era o "estrangeiro" e o "inimigo", visto como inculto e incivilizado. Para Freud, a guerra mostrava o fracasso da civilização ocidental.

\section{A Educação Hebraica}

No período de publicação do manual didático de Theobaldo Miranda Santos a ideologia antissemita era bastante presente, inclusive em círculos católicos de tendência fascista e integralista. Reich (2001) assinalou para "a presença de padres em grupos fascistas" (p.186). Por outro lado, como o grupo católico não era homogêneo, havia "grupos de católicos internacionais comprometidos com a social democracia" e alguns também vinculados ao "anarquismo" (p.216-217). Na visão do fascismo, o judeu representava a "destruição da civilização" (p.73).

Santos (1960) abordou a educação hebraica em uma perspectiva idealista e espiritualista. Procurou compreender o "espírito hebraico", bem como a sua "vida espiritual". A expressão espírito é recorrente no livro de Theobaldo, o que revela indícios de sua leitura de autores vinculados com o idealismo alemão. Enalteceu religião judaica, no entanto, ressaltou que o judaísmo levou ao surgimento do cristianismo. Temos uma visão cristã e católica do judaísmo. A respeito das críticas, demonstrou que os judeus tiveram "desprezo pela ciência e a filosofia". A figura abaixo ilustra o sumário do livro de Theobaldo Miranda Santos, ao tratar do tema da educação hebraica. 


\section{A EDUCAÇ̃̃O HEBRAICA}

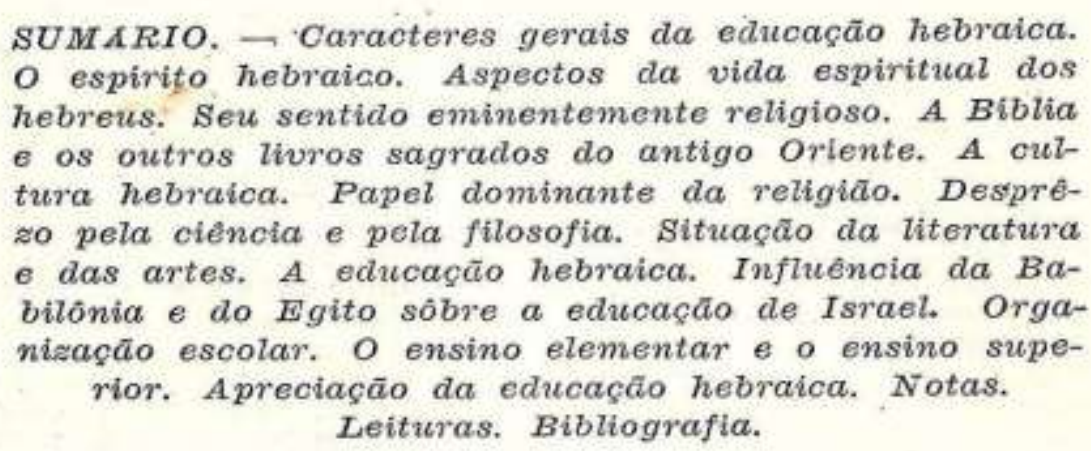

Figura 1: Sumário do Capítulo sobre Educação Hebraica

Fonte: Santos (1960, p. 64).

O intelectual enalteceu o aspecto religioso do povo judeu. Destacou sua religião monoteísta como a grande contribuição judaica para a cultura. A Bíblia, utilizada pelos cristãos, seria a expressão da literatura e poesia hebraicas. Como considera Eliade: "A religião de Israel é acima de tudo uma religião do Livro" (ELIADE, 2010, p. 162). Sustentou que os hebreus, em suas Escolas ou "casas de estudos", divididas em "Mikrah", "Mishnah" e "Guemara", usaram "métodos didáticos intuitivos e atraentes". Mostrou o papel educativo das Sinagogas, com suas escolas em anexo. Para Santos (1960), os judeus sabiam "ensinar o alfabeto por meio de histórias e jogos". Os rabinos foram insignes mestres, que utilizavam do ensino por meio da oralidade, utilizando principalmente a "repetição" e a "revisão". O Talmude seria o grande "guia didático" para o rabino (a palavra rabi quer dizer mestre) na educação da criança. Os rabinos ensinavam o valor das festas religiosas e principalmente do Sábado. Ainda, eles "só admitiam as punições físicas em casos excepcionais" como a "rebelião" e a "preguiça". (p.67). Ao lado do Talmude, a Cabala, numa perspectiva mais mística e especulativa também seria outra referência hebraica para a educação da criança. 


\section{Evolução da educação hebraica}

A evoluçăo da educação entre 05 hebreus pode ser dividida

nas seguintes fases:
1. - Antes do cativeiro na Babilônia: Durante êste periodo a educaçāo era puramente familiar. Năo havia escolas. As erianças reeebiam dos pais a instruçẩo moral e religiosa Todacompletava os ensinamentos ministrados pela Sinagoga, profevia, nessa fase teriam aparecido as primeiras escolas de prof

tas que, na fase seguinte, tomariam grande desenvo da Babilônia 2. - Do cativeiro à era eristā. O cativeiro da Babilonia estimulou o espirito nacional dos hebreus. Sentiram a ideais, através da dade imperiosa de manter a pureza dos seus ideais, atraves de Israel. disseminaçāo da instrução escolar a todos os filhos ocasião do Fol a chamada instruçấo talmúdica. Alem nåo era mais possível regresso do eativeiro. o ensino doméstico na mais ler nem escreporque a maior parte dos judeus nảo sabia mais ler num ensino ver a língua hebraica. Deve-se a Esra a rundaçán prescritas por público, que começou pelas reunioes septena completadas por esMoisés no Deuteronômio, que depois foram complotadas a primeira colas biblicas. Mas a primeira escola para crianças, a póm por Si"Casa do Livro" parece ter sido fundada em Jerusadém pabinos. mäo Ben Sebatach, chefe do Sinédrio, por conselno da hiparquia, Outras foram criadas por determinação dêstes, em cada hiparquia, para rapazes de 16 a 17 anos, que foram, entretanto, povo em qüentadas. Mas depois do Cristianismo que separou sacerdote Joszé duas correntes religiosas, resolveu o grande sacerdote Josz Ben Gamala impor a cada cidade, sob pena de excom rio, näo obrigação de manter uma escola, e mesmo duas, se umes. A próatravessado por uma ponte, a dividisse em duss partes. pria sinagoga podia ser convertida numa escola, se a cidaco muito fôsse muito pobre para criar uma. O dominio Israel. Houve contribuiu também para a expansäo escolar em Israel. Houve necessidade da criaçẫo de muitas escolas a fim de impedir que as

\section{NOÇŌES DE HISTÓRIA DA EDUCAÇÃo}

novas geraçōes fôssem contaminadas pelas doutrinas pagấs trazidas pelos conquistadores.

3. - Da era cristâ ao século $X: 0$ advento do Cristianismo concorreu, de modo particular, para o desenvolvimento educa, encional de Israel. E o contato com a cultura do à influência do sino hebreu um caráter mais oientifico, devida se nesse periodo espírito positivo e prático dos romanos. Nota dos mestres que um grande interêsse pela formação cuidadosa dos mestres devodeviam ser escolhidos entre 08 homens sábios, pacientes no mundo tados. A partir do século $\mathrm{X}$, os judeus disseminados no da culocidental desempenharam papel saliente na expansão da cula tura, como tradutores de obr

filosofia grega e arábiea.

T.M.S.

Figura 2: Evolução histórica da Educação Hebraica

Fonte: (SANTOS, 1960, p.70-71).

Do ponto de vista histórico, na intenção de promover uma periodização da educação hebraica, Theobaldo realizou a seguinte divisão. Entendeu o estabelecimento de três períodos: 1) Antes do cativeiro da Babilônia; 2) Do cativeiro à era cristã; 3) Da era cristã ao século X. Não justificou o porquê de sua escolha. No entanto, a educação hebraica foi entendida com base em dois acontecimentos: o cativeiro (ou exílio) da Babilônia e a era cristã. Esses acontecimentos marcaram a educação hebraica, segundo Theobaldo Miranda Santos. O intelectual sustentou que o cativeiro estimulou o "espírito nacional dos hebreus". Ora, sabemos que o Estado de Israel só foi criado em 1947, após a Segunda Guerra Mundial. Não havia nação hebraica no século V a.C., no período da deportação babilônica. 
O povo judeu vivia sob domínio estrangeiro, dos grandes impérios da antiguidade, tais como os egípcios, os assírios, os persas, os gregos e os romanos. Falar de "espírito nacional hebreu" parece um despropósito, ao menos naquele contexto histórico.

Zizek (2008, p.339) considera que é possível aproximar o sionismo, movimento radical do judaísmo, com o nazismo alemão no tema da criação de um Estado judeu. A Alemanha do período nazista queria se ver livre dos judeus, por outro lado, os sionistas almejavam a criação de um Estado hebreu. Nesse ponto, podemos identificar uma convergência. Um Estado resolveria aparentemente o problema da "questão judaica".

Para Edward Said (2012), "o sionismo parece ter culminado na criação do Estado de Israel" (p.64). Desta maneira, nos dias atuais, o sionismo é um autêntico obstáculo na resolução do conflito entre Israel e Palestina. Seria preciso resistir "ao costume sionista de equiparar antissionismo e antissemitismo". A prática sionista levaria "a apoiar a discriminação racial dos não judeus na Palestina" (p.65). Assim, o sionismo insiste, tanto quanto o nazismo o fez, na "ideologia da raça". Há uma crítica de Theobaldo ao "orgulho racial" judaico.

Theobaldo também encontrou a prática da "excomunhão" entre os judeus. Tenta atribuir ao judaísmo uma prática católica. Ainda, segundo o autor, "o advento do cristianismo concorreu, de modo particular, para o desenvolvimento educacional de Israel" (SANTOS, 1960, p. 71). Interessante que o intelectual utiliza a expressão Israel, designando assim indícios de que já conhecia o recém-criado Estado judeu.

O antissemitismo foi uma preocupação de Walter Benjamin. No apêndice de suas famosas teses sobre a história, o filósofo exclamou: "os judeus estavam proibidos de investigar o futuro". Embora Benjamin (2010) se refira à noção de tempo para o judaísmo como o "Agora" (jetztzeit) e ao critério de "presentificação anamnésica" (Eingedenken), do ponto de vista da historicidade, a afirmação revela uma falta de perspectiva de futuro dos judeus. Talvez isso seja um indício da perseguição dramática enfrentada por eles naquele momento histórico. No entanto, o autor não deixou de insistir que o tempo para os judeus não era "homogêneo e vazio", uma vez que ele "era a porta estreita por onde devia entrar o Messias" (p.20). Um tema mais complexo seria pontuar a relação dialética entre judaísmo e cristianismo (ou catolicismo). Para recorrer novamente a Adorno e Horkheimer, a "negação" dos adeptos da religião do Filho em relação à religião do Pai. Do ponto de vista dialético, a reconciliação entre os opostos seria o momento culminante da história.

Maior dificuldade encontramos no estabelecimento da relação entre capitalismo e religião. Benjamin (2010) foi categórico: “O capitalismo apresenta-se como religião". Há uma imbricação entre a história do cristianismo e a história do capitalismo, a síntese mais nítida dessa relação seria o calvinismo. Afirmou: "A história do cristianismo se tornou essencialmente a do seu parasita, o capitalismo" (p.32). A respeito do catolicismo, conjecturou: "O problema do catolicismo é a teocracia (falsa e terrena)". Mais adiante explicou: "O verdadeiro poder divino só no mundo por vir (da plena realização) pode se manifestar de forma não destruidora". O Catolicismo, segundo suas ideias, acreditaria no poder terreno baseado em um "princípio supremo". Mas não existe "neste mundo nada permanente" (p.29). Eis algumas críticas de Benjamin ao cristianismo. 


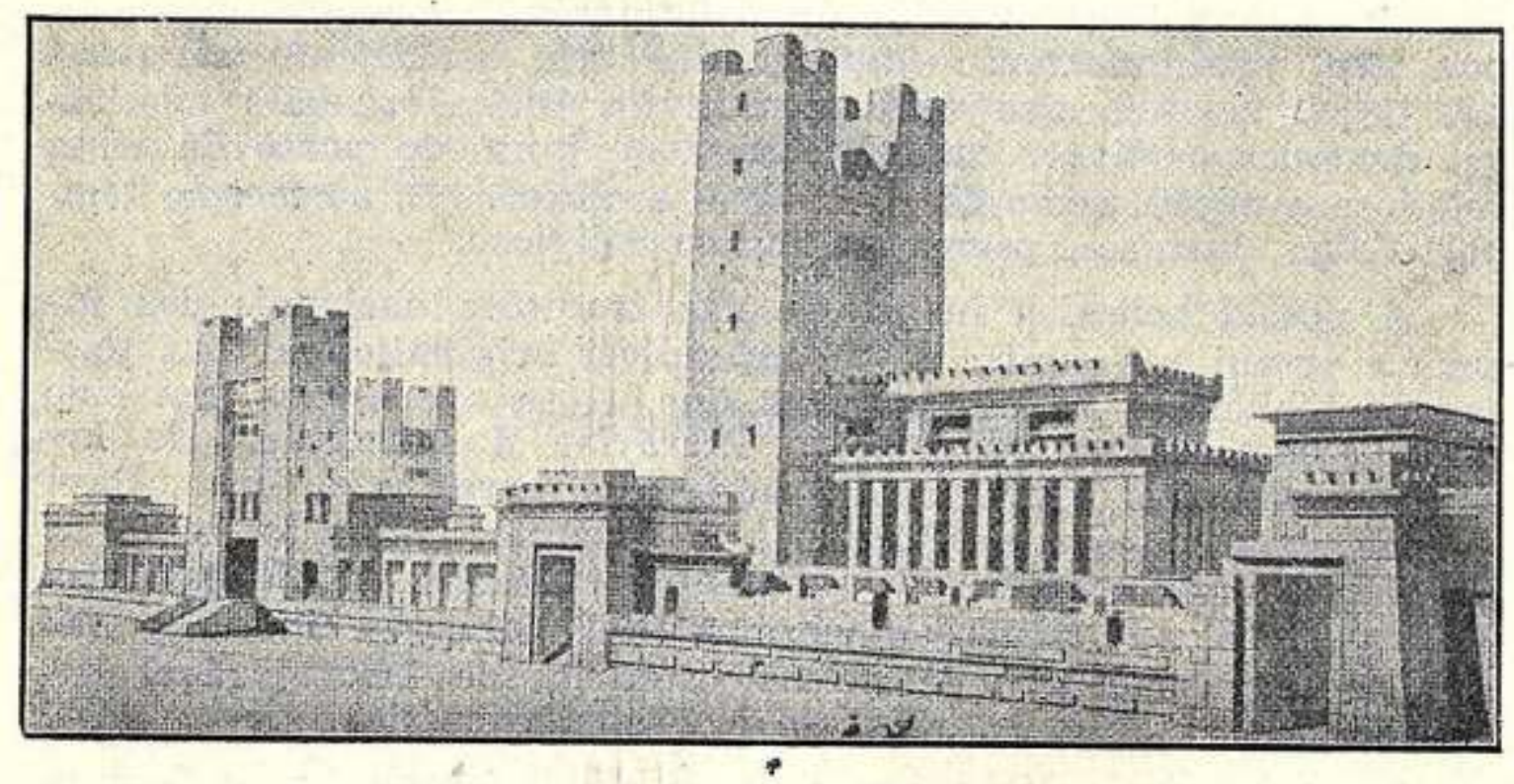

Reconstituịăo do templo de Jerusalém.

Figura 3: Ilustração do antigo Templo de Jerusalém.

Fonte: (SANTOS, 1960, p.66).

O manual didático de Theobaldo Miranda Santos silencia sobre a perseguição que os judeus sofreram por parte dos católicos durante o período da inquisição medieval. Há também um silêncio sobre a perseguição empreendida pelos nazistas aos judeus exatamente naquele momento histórico. O silêncio de Theobaldo encontra eco no "silêncio do papa [Pio XII] em relação ao Holocausto" (ZIZEK, 2008, p. 480). Zagheni (2011, p. 326-334), indica um intenso debate historiográfico (inclusive na historiografia católica), sobre os "silêncios" de Pio XII. Ao mesmo tempo em que Theobaldo afirmou o "desprezo dos judeus pela filosofia e as ciências", ele enalteceu o papel dos hebreus como "vulgarizadores" da filosofia grega e arábica. Parece haver uma contradição em suas ideias. Lembrava Freud: "O povo judeu, espalhado por todo o mundo, prestou assim meritórios serviços às civilizações que o acolheram; infelizmente, nem todos os massacres de judeus ao longo da Idade Média bastaram para fazer desta uma era mais pacífica e segura para os cristãos". Lembrou ainda: "Que o apóstolo S. Paulo tenha proclamado o amor universal entre os homens como fundamento da sua comunidade cristã teve como consequência inevitável a intolerância do cristianismo para com aqueles que ficaram de fora" (FREUD, 2008, p. 69). De acordo com a afirmação de Freud, o cristianismo havia se tornado uma religião intolerante com os judeus no seu tempo.

A intelectual Maria Lacerda de Moura (1934) afirmava que "Pio XI é um antifascista de última hora" (p. 203). Para a líder anarquista, "a Igreja apoiou o Duce e foi cúmplice de todas as suas tiranias e tinha interesse que o homem 'enviado pela Providência' salvasse os seus capitais, as suas propriedades e o seu poder espiritual ameaçado pela avalanche da pedra que vem rolando" (p.204). Afirmava ainda que, "quando todos os crimes abomináveis eram perpetrados na Itália, toda a Igreja Romana, o papa, cardeais, inclusive Dom Sebastião Leme, todos cognominavam a Mussolini, o homem da Providência, era a prudência da serpente" (p.208). Não há dúvidas de que a 
Igreja apoiou o regime de Mussolini e que só rompeu tardiamente com o líder fascista após ter seus interesses atendidos. "O fascismo nasce anti-clerical e anti-religioso e se tornará, em relação à Igreja católica, um regime concordatário. [...] O fascismo tinha necessidade, pois, de um aliado, e este só podia ser a base católica" (ZAGHENI, 2011, p. 274). Ressalte-se que o silêncio do papa ante as atrocidades do fascismo é constrangedor e disso pode-se perceber claramente as contradições das críticas da Igreja ao totalitarismo no século XX.

David Kertzer (2003), em sua obra $O$ Vaticano e os Judeus: os papas e a ascensão do anti-semitismo moderno, trata com profundidade do antissemitismo entre os papas, especialmente na ideias de Achilles Ratti, o papa Pio XI. Argumentou Kertzer, que Ratti, que fora núncio apostólico na Polônia antes do pontificado, mostrou nítidos traços de antissemitismo nos seus relatórios destinados ao secretário de Estado do Vaticano. Achilles Ratti entendia que "os judeus também eram responsáveis pelas tentativas comunistas de solapar a Polônia” (p.326). Já como Pio XI “o papa pensava que os judeus na Itália alguns dos quais havia conhecido - eram basicamente bons. Mas a massa dos judeus do continente, as hordas de judeus que viviam na Europa central e do leste eram coisa completamente diferente, uma ameaça à sociedade cristã saudável - uma lição que aprendera na Polônia" (p.327). Uki Goñi (2004) entendeu que a Igreja desse período vivia uma "paranoia comunista" que levou a um "antissemitismo" (p.135). Havia a crença em uma "conspiração financeira internacional judaica" (p.270). Viva-se na Igreja o medo do "complô maçônico-comunista" (p.155) e do "capitalismo judaico" (p.255). Os judeus e os comunistas eram entendidos como "inimigos" do nacionalismo católico. Por isso, o regime do corporativismo católico era "clerical e anti-hebreu" (p. 225). Segundo suas ideias, a Ação Católica representava "a cruzada anticomunista da Igreja" (p.117). A importância de Pio XI, que ficou conhecido na história como papa da Ação Católica, para Theobaldo Miranda Santos (1939) foi fundamental. Assim como outros intelectuais católicos do período, o personagem estabeleceu diálogo com as reflexões do pontífice. Sempre em textos elogiosos e de tom laudatório, inicialmente publicados na Revista $A$ Ordem e depois transcritos para os seus manuais didáticos (aproximadamente 150 livros).

Eric Hobsbawm assinalou que a Igreja não era diretamente vinculada ao fascismo. Porém, sua aparente neutralidade levanta suspeita e debates historiográficos. Registrou sua análise das relações entre a Igreja e o fascismo nos seguintes termos:

A Igreja Católica Romana, profunda e inflexivelmente reacionária como era a sua versão oficial consagrada pelo primeiro Concílio Vaticano de 1870, não era fascista. Na verdade, por sua hostilidade a Estados essencialmente seculares com pretensões totalitárias, veio a sofrer oposição do fascismo. Mas a doutrina do "Estado corporativo", melhor exemplificado em países católicos, foi em grande parte elaborada em círculos fascistas (italianos), embora estes, é claro, tivessem recorrido à tradição católica para fazê-lo. Esses regimes chegaram a ser chamados de "clerical fascistas" e fascistas em países católicos vinham diretamente do Catolicismo integrista [...]. A ambiguidade da atitude da Igreja em relação ao racismo de Hitler já foi muitas vezes comentada [...]. A era fascista assinalou uma virada na história católica (HOBSBAWM, 2011, p. 118, grifo nosso).

Apesar de Pio XI dirigir críticas ao fascismo, através da encíclica Non Abbiamo Bisogno (1931) e reprovar o nazismo com a carta Mit Brennender Sorge (1937), é possível 
identificar a sua defesa da doutrina do Estado corporativo, especialmente na encíclica Quadragesimo anno (1931). Alcir Lenharo (1986, p. 162-163), encontrou entre os números 90 a 95 da encíclica Quadragesimo anno ideias ligadas com a divulgação da doutrina do Estado corporativo. Para Romano (1979) e Beozzo (1984), os exemplos mais representativos da aproximação da Igreja com o fascismo e o nazismo foram o Tratado de Latrão (1929), firmado com Mussolini e a Concordata do Reich (1933), assinado com Hitler. Entretanto, Roberto Romano alertou: "a Igreja não esteve solitária nesta mão dada ao nazismo" (ROMANO, 1979, p.147). Referia-se àquilo que Trotsky (2013) chamou de "pactos de Stálin com Hitler", ou seja, os acordos do regime stalinista com o nazismo. Sem a colaboração da Igreja e do regime de Stálin, o nazismo possivelmente não teria se consolidado na Alemanha. Trata-se de um problema histórico investigar as relações entre a Igreja e o Estado autoritário (entre os quais é preciso destacar os regimes de Franco, na Espanha e de Salazar, em Portugal) nas décadas de 30 e 40 do século XX. Outra questão a ser discutida é as nuances do corporativismo católico da época.

Segundo Zizek, temos de perguntar: "Por que os judeus representavam um obstáculo para a Europa?". O antissemitismo seria "o avesso do esclarecimento e da democracia europeia". De acordo com seu pensamento: "A Europa representa o sonho grego e cristão". Nesse sentido, o judeu seria um empecilho para esse padrão de civilização europeu (ZIZEK, 2008, p. 337-338).

Dentre as observações críticas, Theobaldo realizou os seguintes apontamentos:

A educação hebraica é criticável em vários aspectos. Entre estes, se
destacam o orgulho racial de povo eleito e o sentimento de extremado
particularismo que fizeram os judeus repudiar os ensinamentos de
fraternidade universal oferecidos pela revelação cristã. Esses caracteres
negativos do espírito judaico refletiram, até certo ponto, a influência da
sua educação. Foi este, sem dúvida, o erro fundamental da educação dos
hebreus. Outro aspecto passível de crítica foi o desprezo dos israelitas
pela investigação filosófica e pela pesquisa científica, o que explica o
atraso, nesta época, de sua cultural intelectual. Mais tarde, porém, ao se
dispersarem pelo mundo, os judeus iriam oferecer à cultura universal uma
floração admirável de grandes filósofos e cientistas. Basta citar os nomes
de Spinosa, Bergson, Meyerson, Freud, Einstein, Max Scheler, para se ter
uma ideia da contribuição dos judeus ao patrimônio da inteligência
humana (SANTOS, 1960, p. 68).

Alain Badiou lembra que na França há um grupo de intelectuais que tenta fazer do "extermínio de judeus pelos nazistas o acontecimento único e sagrado do século XX". Ao mesmo tempo, transformam o antissemitismo "no conteúdo destinal da história da Europa". Desse modo, "a palavra judeu seria a designação vitimária de um absoluto sobressalente". Esses axiomas históricos: o Holocausto e o antissemitismo ocultariam "a política colonial do Estado de Israel", contando com o irrestrito apoio do exército norteamericano, em relação aos árabes (BADIOU, 2007, p. 250). Talvez Edward Said (2012) esteja certo ao afirmar que no século XXI a "questão judaica" se transformou em "questão palestina”.

Segundo Theobaldo, a educação hebraica seria passível de crítica por demasiado "orgulho racial", "sentimento de particularismo (povo eleito)" e ter "rejeitado a fraternidade universal", proposta pelo cristianismo. Aliás, esse seria o "principal erro do 
espírito judaico", rejeitar a revelação cristã. O judaísmo consiste na "mais radical afirmação de um monoteísmo sistemático, visto que a própria existência de outros deuses é negada" (ELIADE, 2011, p. 220). Por outro lado, o intelectual demonstrou a contribuição dos judeus para a cultura e o pensamento e citou alguns nomes como: Spinosa, Bergson, Meyerson, Freud, Einstein e Max Scheler.

Sem dúvidas, Theobaldo Miranda Santos não foi um antissemita militante, como Gustavo Barroso, por exemplo.

Se dissermos a um caboclo cearense que ele pena no eito, come mal, não
é educado e seu país não tem dinheiro para libertá-lo de vez das secas,
por que os judeus de Londres e Nova Iork, Rothschilds e Dillons, sugam
em impostos o melhor que todo o brasileiro produz, porque há um grupo
de judeus acastelados em São Paulo, cúpula da economia nacional, que
manobra o café, arrasa a nação com negociatas, interfere secretamente em
toda a vida brasileira, desde a lei das tarifas até a própria constituição da
República, ele não entenderá nada. Todavia é a verdade nua e crua
(BARROSO, 1937, p. 25 ).

Em sua reflexão "Santo Tomás e o Talmud", Gustavo Barroso criticou duramente o pensamento de Spinosa. Na sua compreensão, seriam as ideias desse filósofo que teriam inspirado a "filosofia talmúdica" do direito. Isso teria como consequência a "horrível heresia de Rousseau" e teria levado a cabo a "concepção de direito naturalista", essa que "tanto fecundou Hobbes". A influência dos judeus no campo do direito foi obra do "judeu luso-holandês", Spinosa, que elaborou sua "Ética", tomada por referência pelo liberalismo (BARROSO, 1937, p. 61). Apesar da crítica do intelectual integralista, outros católicos como Jackson Figueiredo, Alceu Amoroso Lima e o próprio Theobaldo Miranda Santos tiveram amplo diálogo com filósofos judeus. Para Jackson e Alceu o pensamento de Bergson foi muito importante (LIMA, 1935). Ambos mostraram grande apreço pelas ideias do filósofo judeu. Já para Theobaldo, é visível sua predileção por autores judeus como Freud e Husserl. Desse modo, suas críticas à educação hebraica não chegam a configurar um antissemitismo militante e nem mesmo uma "questão judaica" no Brasil. Contudo, revelam uma tentativa de culpar os judeus por "rejeitarem a fraternidade universal do cristianismo". Além do já mencionado silêncio em relação ao Holocausto.

Fábio Koifman (2002) sustentou que havia durante a era Vargas, no Estado Novo, um debate no governo entre intelectuais americanistas e germanófilos. Theobaldo Miranda Santos pertencia ao grupo dos germanófilos. Koifman demonstrou a repercussão do discurso de Getúlio Vargas A posição do Brasil na América, realizado em 1940, após a invasão nazista na França, que deu início ao regime de Vichy. Os jornais da época interpretaram o discurso de Vargas como uma aproximação do antissemitismo. Entre os intelectuais antissemitas presentes no governo varguista estavam Francisco Campos, Filinto Müller e Azevedo Amaral (CARNEIRO, 1988). O "judeu" era um dos "inimigos públicos" do fascista, ao lado do comunista e do liberal (FREITAS, 1998, p. 17). Na citação abaixo, é possível perceber indiretamente uma referência de Vargas ao antissemitismo.

É fácil descobrir e identificar êsses elementos nocivos entre os aproveitadores de todos os tempos, os preparadores de guerras, os sem pátria, prontos a tudo negociar, os que, tendo-a, não sabem defendê-la. Muitos dêles, indesejáveis noutras partes, infiltraram-se 
clandestinamente no país, com prejuízo das atividades honestas dos nacionais e, abusando da nossa hospitalidade, fazem-se instrumento de maquinações e intrigas do financismo cosmopolita, voraz e sem escrúpulos. A êsses não me dirigi, certamente. Falei aos brasileiros e aos que se sentem no Brasil como na própria pátria; e tenho a certeza de que os acontecimentos se incumbiram de tornar ainda mais evidentes as minhas afirmações. Responsável direto pelo futuro do nosso povo, não tenho o direito de deixá-lo iludir-se ou induzi-lo a erros de puro sentimentalismo (VARGAS, 1940, p.348, grifo nosso).

A figura 4 demonstra traços da aproximação dos católicos com os integralistas, nas páginas de uma obra de Gustavo Barroso permeada de antissemitismo e de admiração do nazismo.

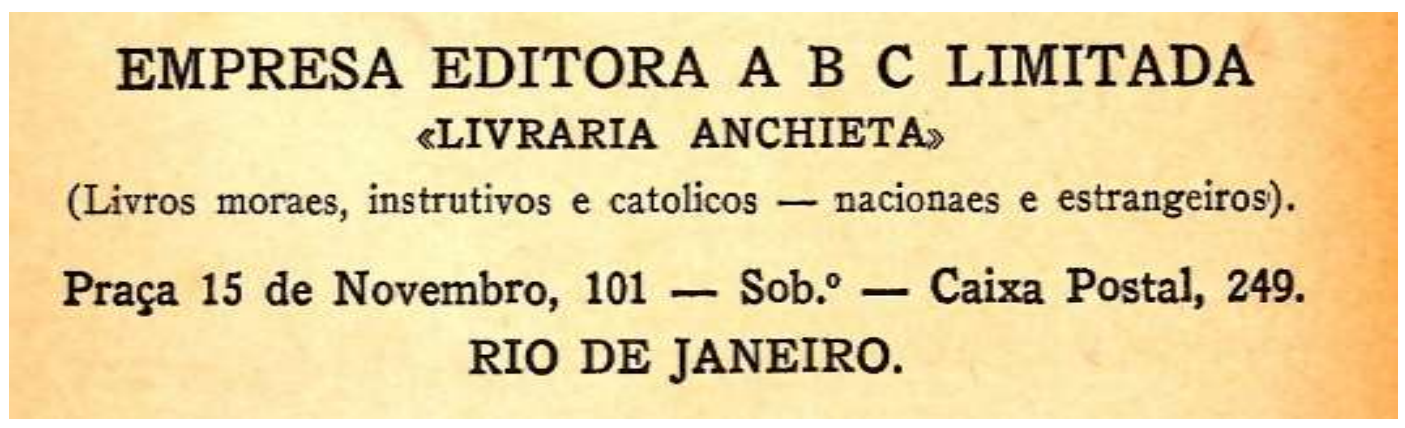

Figura 4: Propaganda da Editora católica ABC, na obra Integralismo e Catolicismo de Gustavo Barroso.

Fonte: Barroso (1937).

Emmanuel Levinas mostrou a intensidade do sofrimento dos judeus na Europa durante a fatídica década de 1930. A perseguição tomava proporções cada vez mais dramáticas e angustiantes. Levinas comparou o povo judeu ao proletariado, dizendo que os proletários são explorados, mas não perseguidos.

Mas aqueles que, há alguns meses, gritavam nas ruas de Paris "somos todos judeus alemães" não podem, apesar disso, ser tidos como culpados de mesquinharia pequeno-burguesa. Judeus alemães em 1933, estrangeiros no curso da história e do mundo, judeus simplesmente, isso significa o que há de mais frágil, de mais perseguido no mundo. Mais perseguido que o próprio proletariado - que é explorado, mas não perseguido. Raça maldita, não por seus genes, mas por seu destino de infelicidade, e provavelmente por seus livros que chamam a infelicidade para aqueles que lhes são fiéis e que os transmitem fora de todo cromossomo. Povo de nosso Deus, nesse sentido preciso (LEVINAS, 2001, p. 48).

Robert Darnton afirmou a importância dos estudos da bibliografia. Para o historiador norte-americano, devemos estabelecer uma conexão entre os estudos de bibliografia e a história do livro. De acordo com suas ideias, "a bibliografia pode transcender os livros" e ajudar a compreender o "sentido do texto". Elas também projetam a obra para além da "crítica textual". Trata-se da "vitalidade da pesquisa bibliográfica" que nos leva a compreender as "formas culturais" (DARNTON, 2010, p. 162). 


\section{BIBLIOGRAFIA}

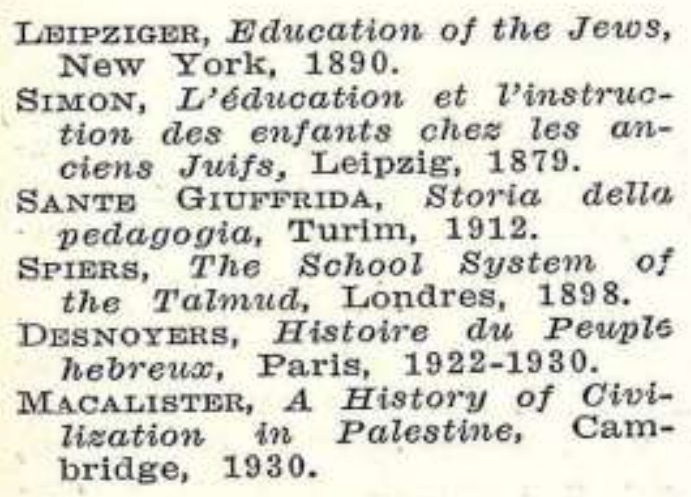

Ruiz Amado, Historia de la Educación y la Pedagogia, Barcelona, 1930.

Riboulet, Histoire de la Pédagogie, Paris, 1935.

P. S. DuGGAN, Student's Textbook in the History of Education, New York, 1936.

MONROE, Cyclopedia of Education, New York, 1925.

Figura 5: Bibliografia do capítulo sobre Educação Hebraica.

Fonte: (SANTOS, 1960, p. 71).

O estudo da bibliografia utilizada por Theobaldo Miranda Santos, como sugere Robert Darnton, indica a utilização de 10 livros. O período de edição contemplado pelas obras utilizadas vai de 1879 a 1936 . Há uma concentração de obras nas últimas décadas do século XIX e nas décadas de 20 e 30 do século XX. A década privilegiada foi a de 1930, que teve 4 obras citadas. Eram obras estrangeiras. Provenientes dos Estados Unidos e da Europa. Os países que foram mais privilegiados na bibliografia: Estados Unidos, França e Inglaterra. Há menção de livros da Itália e da Espanha. Apenas uma obra editada em Leipzig, na Alemanha, mas escrita em língua francesa, foi citada por Theobaldo.

\section{Um Comentário Crítico}

Para Hannah Arendt, os primórdios do movimento antissemita datam, em toda parte "do último terço do século XIX". Para a filósofa, "na Alemanha começou, de modo inesperado, novamente entre a nobreza, cuja oposição ao Estado foi provocada pela transformação da monarquia prussiana num Estado-nação, completado depois em 1871". Bismarck desempenhou papel fundamental de "verdadeiro fundador do Reich alemão", ele também "havia mantido estreitas relações com os judeus desde a época em que era primeiro-ministro". Agora ele era acusado de "depender e aceitar suborno dos judeus" (ARENDT, 2007, p.55).

Havia uma relação de corrupção entre os judeus ricos, banqueiros, industriais e agiotas, com inúmeros governos da Europa. "Essa íntima relação entre judeus e governos era facilitada pela indiferença geral da burguesia no tocante à política em geral e às finanças do Estado". Segundo Arendt, os judeus estavam por trás o imperialismo das grandes potências europeias do século XIX. A questão refere-se aos embates relacionados com o imperialismo e a formação do Estado-nação. No centro do problema, os negócios dos judeus ligados ao grande capital financeiro com Estado (ARENDT, 2007, p.35). Para uma melhor compreensão do assunto, sugerimos uma leitura atenta da primeira parte o livro de Hannah Arendt, "Origens do Totalitarismo", no qual a autora desenvolve em detalhes o tema do antissemitismo e de suas relações com o imperialismo. 
Como já tivemos oportunidade de afirmar, não há na obra de Theobaldo Miranda Santos um antissemitismo militante e tão pouco indícios de uma "questão judaica" no Brasil. Nesse ponto, ele não foi tão radical como outros intelectuais integralistas que insistiram mais na publicação de uma literatura anti-judaica nas décadas de 1930 e 1940. Há um diálogo com autores de origem hebraica, como Freud e Husserl, por exemplo. A literatura manipulada pelo intelectual para tratar da educação hebraica não tem origem na Alemanha, apesar do autor apresentar grande apreço pelo pensamento alemão em suas várias obras. Nem mesmo antissemitas notórios, como Gustavo Barroso, não são citados na obra. Entre os intelectuais brasileiros, apenas Jônatas Serrano recebeu uma citação (SANTOS, 1960, p. 70).

Ao examinar o tema da "educação nacionalista", Theobaldo Miranda Santos criticou tanto o "nacionalismo fascista ou italiano" quanto o "nacionalismo nazista ou alemão". Entendeu que "com o racismo nazista, o nacionalismo atinge sua exasperação máxima e sua feição mais exaltada, materialista e brutal". Sustentou que o "nacionalismo totalitário acabou por se contradizer a si mesmo". Desse modo, a perspectiva nacionalista, tal como foi desenvolvida pelo fascismo e pelo nazismo seria caracterizada pelo "ilogismo" e a "unilateralidade dos pontos de vista" (SANTOS, 1944, p. 162-165). Não há menção ao judaísmo ou ao Holocausto. Theobaldo se concentra na crítica do "racismo nazista" de modo geral. Essas reflexões, contidas na obra "Introdução à Pedagogia Moderna”, publicada em 1944, pela editora "A Noite”, do Rio de Janeiro, já mostram uma postura mais crítica em relação ao fascismo.

Esse mesmo texto foi publicado como um capítulo do manual didático "Noções de História da Educação", intitulado "A Educação Nacionalista". Theobaldo insistiu que o "verdadeiro" nacionalismo seria o "nacionalismo cristão", tal como era defendido por Alceu Amoroso Lima. Assim, empreendeu uma crítica ao fascismo e ao nazismo. Nesse período já era possível identificar críticas dos católicos ao regime fascista. Tristão de Athayde (Alceu Amoroso Lima), em sua obra Debates Pedagógicos (1931), citou: “"Nada, entretanto está feito, quando tudo não está feito', dizia recentemente Mussolini, numa das suas phrases felizes. E é isso o que devem pensar os catholicos, mesmo victimas de juízos injustos" (ATHAYDE, 1931, p. 135). Estabeleceu-se uma identificação dos católicos com Mussolini. Há também um diálogo amistoso com as ideias de Francisco Campos nesta obra. Mas tal postura seria alterada com o tempo. O líder do Centro Dom Vital se aproximou do humanismo integral de Jacques Maritain (1936), e abandonou posições integristas para rumar à democracia cristã. Em 1938, já era possível encontrar nas ideias de Alceu Amoroso Lima (1938) uma crítica contundente do nazismo, ao qualificá-lo como "lógica satânica" (p. 379). Ainda, em sua análise do "problema nacionalista", havia a referência ao pensamento de Charles Maurras (1868-1952), (“o positivismo nacionalista"), argumentou "esse nacionalismo integral e tradicionalista foi o que Maurras pregou antes que outro qualquer e ia ser a fonte de todos os hiper-nacionalismos contemporâneos" (p.372-373). 


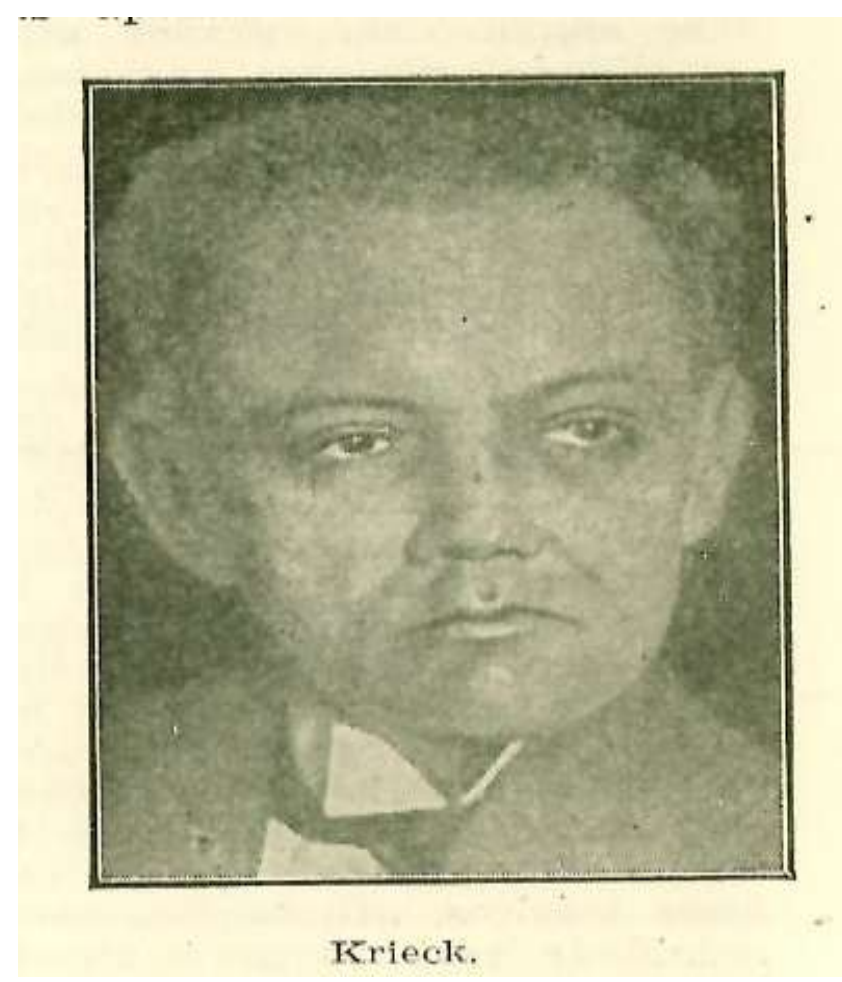

Figura 6: Fotografia do "pedagogo nazista” Ernst Krieck (1882-1947).

Fonte: Santos (1960, p. 383).

Theobaldo não citou Charles Maurras, contudo, se referiu a Ernst Krieck (18821947), o famoso "pedagogo nazista", nomeou a obra Das Wesen der Erziehung (A Essência da Educação), de 1928. O intelectual se preocupou em ilustrar o seu manual didático com uma imagem deste pensador alemão. Porém, usou as reflexões de Frans De Hovre e de G. K. Chesterton para rejeitar o "nacionalismo pedagógico totalitário". Entendia "a nação, o Estado e a Raça" como "valores reais", mas não como "valores absolutos" (SANTOS, 1960, p. 385). Não houve qualquer menção aos judeus nesse capítulo, porém, se tem uma apresentação cuidadosa da "educação nacionalista", inclusive com a tradução de trechos diretos da obra de Krieck.

Podemos afirmar que a consagração de Theobaldo Miranda Santos como um intelectual inserido no campo editorial, como defendeu Pierre Bourdieu (2011), se deu pela mediação de Alceu Amoroso Lima. A "conversão" de Theobaldo foi "obra" de Alceu. Mas também foi obra do líder da Ação Católica no Brasil, a inserção do autor no grande mercado editorial. Nas páginas da Revista A Ordem, quando editada por Alceu, Theobaldo foi consagrado como intelectual e homem de letras. Somos levados a crer que sem essa mediação de Alceu Amoroso Lima, o intelectual não teria alçado os postos mais altos do campo editorial brasileiro, a ponto de publicar seus principais livros na Companhia Editora Nacional, na qual teve uma coleção exclusiva para seus escritos.

A investigação do tema da "educação hebraica" se deve também às afirmações de Cândido Moreira Rodrigues (2005), de que uma das "matrizes teórico-filosóficas" da Revista A Ordem, ao lado de Edmund Burke (1729-1797), Louis-Ambroise De Bonald (1754-1840), Joseph De Maistre (1753-1821) e de Juan Donoso Cortés (1808-1853), era as ideias do "jurista alemão católico e nazista" Carl Schmitt (1888-1985). Além disso, é 
preciso mencionar os filósofos Henri Bergson (1859-1941) e Jacques Maritain (18821972). Mas insistiu o pesquisador que "no interior da revista, os posicionamentos não eram totalmente unânimes", o que dispensaria de imediato uma análise "simplista" do periódico (RODRIGUES, 2005, p. 173).

$\mathrm{Na}$ análise de Célia Maria Groppo, é possível identificar alguns discursos antissemitas publicados na Revista $A$ Ordem. Em sua dissertação de mestrado perguntou a pesquisadora: "A Ordem era uma revista anti-semita? Esta não é uma pergunta de resposta simples". Para a autora, tal pergunta causaria "até hoje", muitos "constrangimentos nos meios católicos" (GROPPO, 2007, p. 89).

O "judeu" pode ser considerado "como fetiche fascista", segundo Slavoj Zizek. Mas tal interpretação carece ser desmistificada. O problema é que "os fetichistas se sentem satisfeitos com seus fetiches, não têm necessidade de se livrar deles". Seria necessário dizer ao 'trabalhador explorado que o 'judeu' é o inimigo errado, promovido pelo verdadeiro inimigo (a classe dominante) com o objetivo de ocultar a luta verdadeira - e, assim voltar sua atenção dos "judeus' para os "capitalistas"” (ZIZEK, 2011b, p. 65). A associação do "judeu" ao "capitalista" é o fetiche ideológico do fascista, que precisamos desmistificar para mostrar a exploração da classe dominante. Edgar Morin lembrou que "muitos acreditavam, tragicamente, que ao colaborar com a Alemanha de Hitler estariam na verdade colaborando com a construção de uma Europa socialista" (MORIN, 2009, p. 18). Este fenômeno foi o que Zizek (2008) chamou de "erro fascista", que teria, por exemplo, sido protagonizado por Martin Heidegger e muitos outros intelectuais.

\section{Considerações Finais}

O intelectual Theobaldo Miranda Santos reconheceu a importância da educação hebraica na perspectiva da história da educação. Apesar de suas críticas ao "espírito hebreu", identificou as contribuições judaicas para a cultura ocidental. Em sua análise, realizou uma crítica do "nacionalismo pedagógico totalitário". Não utilizou literatura antissemita para tratar desse tema, considerado ao menos delicado para a época. No contexto de publicação do seu manual didático "Noções de História da Educação", as ideologias do nazismo e do fascismo eram ainda muito presentes e atuantes. No Brasil, o Integralismo foi o intérprete dessas ideologias. Nem mesmo fez menção à "questão judaica", presente nas ideias de Marx. Theobaldo foi consagrado como intelectual nas páginas da Revista $A$ Ordem, que difundiu no Brasil a "pregação anti-revolucionária ou reacionária, direitista, fascista ou parafascista" (IGLÉSIAS, 1981, p. 110). Não incorreu na interpretação fetichista do "judeu", como os intelectuais protofascistas. Isto não significa afirmar que a "questão judaica" tivesse desaparecido. Tal tema sempre apareceu correlacionado com outras categorias de análise do pensamento marxista, tais como imperialismo, colonialismo e totalitarismo. Assim como o Estado para Marx não é algo estanque, fixo e determinado, mas algo que se "metamorfoseia" (SADER, 2014, p. 78), que assume diferentes características ao longo da história, o mesmo pode ser dito da "questão judaica". Ela não desapareceu, apenas sofreu uma metamorfose. O mesmo vale para as noções de imperialismo e colonialismo. Ambas também se transformaram.

Pensadores como Edward Said (2012) e Tariq Ali (2002) mostram a permanência dos ideais do imperialismo nos atuais conflitos na Palestina e no Oriente Médio. Uma vez 
que o problema é "territorial", expressão do sonho imperialista do século XIX. A criação do Estado de Israel não resolveu a "questão judaica". O capitalismo, em nossa era supostamente "pós-ideológica", ganhou outros nomes: globalização, imperialismo, crise ecológica, fundamentalismo religioso (islâmico), multiculturalismo, migração, entre outros. Tariq Ali vê na "jihad islâmica" uma tentativa desesperada de um "antiimperialismo de tolos" (ALI, 2002, p. 179). Na análise de Noam Chomsky, sobre o atentado de 11 de Setembro de 2001 ao "World Trade Center", em Nova Iorque, há a dúvida de que as motivações do grupo de bin Laden tenham sido anticapitalistas ou antiglobalização. Insistiu o pensador norte-americano: "a rede de bin Laden não tem preocupações relevantes quanto à globalização e à hegemonia cultural [...]. Eles têm dito para nós, em alto e bom tom, no que consiste suas preocupações: estão promovendo uma Guerra Santa contra os regimes não-islâmicos, corruptos e repressores da região, contra todos que os sustentam. O próprio bin Laden, muito provavelmente, jamais ouviu falar em globalização"(CHOMSKY, 2005, p. 34). No seu entendimento, as motivações do atentado teriam advindo do fundamentalismo religioso e não de uma militância anticapitalista. Exemplos hodiernos desse fundamentalismo islâmico seriam os grupos ISIS (Estado Islâmico do Iraque) e Boko Haram.

Theobaldo Miranda Santos nem de longe foi um entusiasta do pensamento judaico. Mas isso não o impediu de ler autores judeus que marcaram o seu pensamento de maneira decisiva, tais como Freud e Husserl. Pensemos na importância de Henri Bergson para os intelectuais católicos do início do século XX, inclusive no Brasil. Mesmo havendo uma estreita relação entre o Integralismo e o Catolicismo, os termos não são equivalentes. $O$ Catolicismo era muito mais complexo e heterogêneo do que o movimento integralista. Escapa, assim, de qualquer análise simplista e superficial. É inegável, também, que o Integralismo e a Igreja se apoiaram mutuamente naquele período histórico. Apesar disso, intelectuais católicos que transitaram entre os integralistas foram leitores de pensadores judeus.

O silêncio de Theobaldo sobre o genocídio sofrido pelos judeus no século XX é constrangedor. Ainda mais em um manual dedicado à história da educação. A escrita do autor não incorreu na tendência historiográfica de "vitimizar" o "judeu". Todavia, intentou atribuir aos judeus a culpa pelo seu próprio flagelo. Podemos conjecturar que a crítica de Theobaldo aos judeus estava fundamentada naquilo que Edgar Morin (2007) chamou de "antijudaísmo cristão" (p.18). Defendeu o autor: "o cristianismo condena a Sinagoga, cega ao verdadeiro Messias" (p.16). Ainda, de acordo com Morin: "pareceu-me indispensável distinguir o antijudaísmo, de origem cristã, e o antissemitismo, nascido no século XIX com o impulso do nacionalismo" (p.12). Para Theobaldo, os judeus rejeitaram a revelação cristã, então pagaram o preço por recusar a "fraternidade universal". Mostrou-se um intelectual católico com críticas baseadas na intolerância ao judaísmo. Esta parece ser a principal ambiguidade do discurso de Theobaldo Miranda Santos ao tratar da educação hebraica. 


\section{REFERÊNCIAS}

ADORNO, Theodor W.; HORKHEIMER, Max. Dialética do esclarecimento: fragmentos filosóficos. Rio de Janeiro: Zahar, 2006.

ALI, Tariq. Confronto de fundamentalismos: cruzadas, jihads e modernidade. Rio de Janeiro: Record, 2002.

ARENDT, Hannah. Eichmann em Jerusalém: um relato sobre a banalidade do mal. São Paulo: Companhia das Letras, 2011.

Origens do totalitarismo: anti-semitismo, imperialismo e totalitarismo. São Paulo: Companhia das Letras, 2007.

ATHAYDE, Tristão de. Debates pedagógicos. Rio de Janeiro: Schmidt, 1931.

BADIOU, Alain. O século. Aparecida: Idéias \& Letras, 2007.

BAUMAN, Zygmunt. Modernidade e holocausto. Rio de Janeiro: Zahar, 2013.

BENJAMIN, Walter. O anjo da história. Lisboa: Assírio \& Alvim, 2010.

O capitalismo como religião. São Paulo: Boitempo, 2013.

BARROSO, Gustavo. Integralismo e catolicismo. Rio de Janeiro: A.B.C, 1937.

BEOZZO, José Oscar. Igreja, educação e cultura: a igreja entre a revolução de 1930, o estado novo e a redemocratização. In: FAUSTO, Boris (Dir.). História geral da civilização brasileira. Tomo III, o Brasil republicano, Vol. 4, economia e cultura. São Paulo: DIFEL, 1984, p.271-341.

BERTONHA, João Fábio. Fascismo, nazismo, integralismo. São Paulo: Ática, 2004.

BOURDIEU, Pierre. Economia das trocas simbólicas. 7 ed. São Paulo: Perspectiva, 2011.

CANCELLI, Elizabeth. O mundo da violência: a polícia da era Vargas. 2 ed. Brasília: Editora UNB, 1994.

CARNEIRO, Maria Luiza Tucci. O anti-semitismo na era Vargas (1930-1945): fantasmas de uma geração. São Paulo: Brasiliense, 1988.

CHOMSKY, Noam. 11 de Setembro. 9 ed. Rio de Janeiro: Bertrand Brasil, 2005.

DARNTON, Robert. A questão dos livros: passado, presente e futuro. São Paulo: Companhia das Letras, 2010.

ELIADE, Mircea. História das crenças e das ideias religiosas: da idade da pedra aos mistérios de Elêusis. Vol.1. Rio de Janeiro: Zahar, 2010.

História das crenças e das ideias religiosas: de Gautama ao triunfo do cristianismo. Vol.2. Rio de Janeiro: Zahar, 2011. 
FREITAS, Marcos Cesar de. Integralismo: fascismo caboclo. São Paulo: Ícone, 1998.

FREUD, Sigmund. Moisés e o monoteísmo. Rio de Janeiro: Imago, 1975.

O futuro de uma ilusão. Porto Alegre: LP\&M, 2012.

O mal-estar na civilização. Lisboa: Relógio D’ Água, 2008.

GOÑI, Uki. A verdadeira Odessa: o contrabando de nazistas para a Argentina de Perón. Rio de Janeiro: Record, 2004.

GROPPO, Célia Maria. Ordem no céu, ordem na terra: a revista A Ordem e o ideário anticomunista das elites católicas (1930-1937). 184f. 2007. Dissertação (Mestrado) Programa de Pós-Graduação em História, Pontifícia Universidade Católica de São Paulo.

HEGEL, Georg Wilhem Friedrich. Filosofia da história. 2 ed. Brasília: Editora UNB, 2008.

HEINE, Heinrich. História da religião e da filosofia na Alemanha e outros escritos. São Paulo: Madras, 2010.

HOBSBAWM, Eric. Era dos extremos: o breve século XX (1914-1990). São Paulo: Companhia das Letras, 2011.

das Letras, 2013.

Tempos fraturados: cultura e sociedade no século XX. São Paulo: Companhia

IGLÉSIAS, Francisco. História e ideologia. 2 ed.São Paulo: Perspectiva, 1981.

KERTZER, David I. O Vaticano e os judeus: os papas e a ascensão do anti-semitismo moderno. Rio de Janeiro: Rocco, 2003.

KOIFMAN, Fábio. Quixote nas trevas: o embaixador Souza Dantas e os refugiados do nazismo. Rio de Janeiro: Record, 2002.

LENHARO, Alcir. Sacralização da política. 2 ed. Campinas: Papirus, Editora UNICAMP 1986.

LEVINAS, Emmanuel. Do sagrado ao santo: cinco novas interpretações talmúdicas. Rio de Janeiro: Civilização Brasileira, 2001.

LIMA, Alceu Amoroso. O nacionalismo cristão. A Ordem. Rio de Janeiro: Centro Dom Vital, 1938, outubro, p.367-391.

. Pela ação católica. Rio de Janeiro: Editora Biblioteca Anchieta, 1935.

MARX, Karl. A questão judaica. São Paulo: Boitempo, 2010.

MORIN, Edgar. Cultura e barbárie europeias. Rio de Janeiro: Bertrand Brasil, 2009.

O mundo moderno e a questão judaica. Rio de Janeiro: Bertrand Brasil, 2007. 
MOURA, Maria Lacerda de. Clero e fascismo: horda de embrutecedores. São Paulo: Editorial Paulista, 1934.

PIO XI. Mit brennender sorge. In: Documentos de Pio XI (1922-1939). São Paulo: Paulus, 2004, p. 523-553.

. Non abbiamo bisogno. In: Documentos de Pio XI (1922-1939). São Paulo: Paulus, 2004, p. 336-369. Quadragesimo anno. In: Documentos de Pio XI (1922-1939). São Paulo: Paulus, 2004, p. 272-335.

REICH, Wilhelm. Psicologia de massas do fascismo. São Paulo: Martins Fontes, 2001.

RODRIGUES, Cândido Moreira. A Ordem: uma revista de intelectuais católicos (19341945). Belo Horizonte: Autêntica, FAPESP, 2005.

ROMANO, Roberto. Brasil: igreja contra o estado (crítica ao populismo católico). São Paulo: Kairós, 1979.

SADER, Emir. Estado e política em Marx. São Paulo: Boitempo, 2014.

SAID, Edward W. A questão da Palestina. São Paulo. Editora UNESP, 2012.

SANTOS, Theobaldo Miranda. Introdução à pedagogia moderna. Rio de Janeiro: A Noite, 1944.

Noções de história da educação. 9 ed. São Paulo: Companhia Editora Nacional,1960.

. Pio XI e a pedagogia moderna. A Ordem. Rio de Janeiro: Centro Dom Vital, 1939, março, p. 298-303.

TROTSKY, Leon. Os pactos de Stálin com Hitler. Curitiba: Sobrado Verde, 2013.

VARGAS, Getúlio. A posição do Brasil na América: discurso pronunciado na Ilha do Viana, ao realizar-se homenagem da federação dos marítimos, a 29 de junho de 1940. Disponível em: <http://www.biblioteca.presidencia.gov.br/ex-presidentes/getuliovargas/discursos-1/1940/23.pdf/download> Acesso: 21/07/2014.

ZAGHENI, Guido. A idade contemporânea: curso de história da igreja IV. 2 ed. São Paulo: Paulus, 2011.

ZIZEK, Slavoj. A visão em paralaxe. São Paulo: Boitempo, 2008.

Em defesa das causas perdidas. São Paulo: Boitempo, 2011 a.

Primeiro como tragédia, depois como farsa. São Paulo: Boitempo, 2011 b.

Recebido: jun-13

Aprovado: out-14 